\title{
Antimicrobial activity of low-pressure plasma treatment against selected foodborne bacteria and meat microbiota
}

\author{
Natalia Ulbin-Figlewicz • Andrzej Jarmoluk • \\ Krzysztof Marycz
}

Received: 11 June 2014 / Accepted: 29 September 2014 / Published online: 19 November 2014

(C) The Author(s) 2014. This article is published with open access at Springerlink.com

\begin{abstract}
The effects of helium and argon plasma treatments on inactivation of both pure bacterial cultures inoculated onto the surface of agarized media and the surface microbiota of meat were investigated. Cold plasmas were generated by high voltage discharge at low pressure $(20 \mathrm{kPa})$ for 2,5 , and $10 \mathrm{~min}$. The number of viable microorganisms was determined using a plate count method. Morphological changes were observed using scanning electron microscopy (SEM). Microbial log reduction depended on time of exposure and type of gas used. After a 10-min treatment with helium plasma, the total number of microorganisms, yeasts and molds, and psychrotrophic microorganisms was reduced in the range of 1.14-1.48 log cycles for pork and 0.98-2.09 log cycles for beef. A significant reduction of $2.00 \log$ for Bacillus subtilis and Yersinia enterocolitica was achieved within $2 \mathrm{~min}$ of helium plasma treatment. Similar results were obtained for Staphylococcus aureus, Escherichia coli and Pseudomonas fluorescens after $5 \mathrm{~min}$ and $10 \mathrm{~min}$ of exposure. SEM revealed disruption and lysis of $E$. coli cells treated with helium plasma for $10 \mathrm{~min}$, suggesting a bactericidal effect.
\end{abstract}

Keywords Antibacterial activity · Bacterial cell $\cdot$ Cold plasma $\cdot$ Decontamination $\cdot$ Low-pressure plasma $\cdot$ Meat

N. Ulbin-Figlewicz $(\bowtie) \cdot$ A. Jarmoluk

Department of Animal Products Technology and Quality

Management, Wrocław University of Environmental and Life

Sciences, ul. Chełmońskiego 37/41, 51-630 Wrocław, Poland

e-mail: natalia.ulbin@gmail.com

K. Marycz

Department of Animal Hygiene and Animal Welfare, Wrocław University of Environmental and Life Sciences, ul. Chełmońskiego

38 C, 51-631 Wrocław, Poland

\section{Introduction}

Microbial hazards are one of the most important issues in the food industry. Meat spoilage is caused by three basic mechanisms: microbial growth, lipid oxidation and enzymatic autolysis (Dave and Ghaly 2011). Those result in discoloration, slime formation, undesirable odors and flavors, and texture softening and make the product unacceptable to consumers. After slaughter and chilling, microbial counts on carcasses are in the range of $10^{1}-10^{5}$ colony forming units $(\mathrm{CFU}) / \mathrm{cm}^{2}$. The types and numbers of microorganisms depend on the initial microbiota, processing, and storage conditions. The most common sources of carcass meat contamination are Pseudomonas spp., Moraxella spp., Acinetobacter spp., Alcaligenes spp., Flavobacterium spp., Aeromonas spp., Staphylococcus spp., Micrococcus spp., coryneforms and Enterobacteriaceae. Meat may be also contaminated by bacterial pathogens, including Salmonella spp., Campylobacter jejuni/coli, Escherichia coli, Listeria monocytogenes, Staphylocccus aureus, Yersinia enterocolitical pseudotuberculosis, Bacillus cereus, Clostridium perfringens and Clostridium botulinum (Sofos 1994; Borch et al. 1996). The most common spoilage microorganism of fresh chilled meat is Pseudomonas spp. These bacteria produce putrefactive odors and slime when their population exceeds $10^{7} \mathrm{CFU} / \mathrm{cm}^{2}$ (Sofos 1994).

The meat industry is an important part of the food manufacturing and processing sector. Between 1960 and 2000, there was a large increase in meat consumption worldwide. The annual per capita consumption increased from $10 \mathrm{~kg}$ to $26 \mathrm{~kg}$ (Dave and Ghaly 2011). In Europe, as a total, $23.8 \%$ of meat and meat products are lost and wasted in the food supply chain. The main sources of loss and waste come from consumption (46\%), processing and packaging (21\%), distribution (17\%), production (13\%), handling and storage (3\%) (Kanerva 2013). Furthermore conventional preservation methods such as refrigeration and modified atmosphere packaging (MAP) technology 
could be insufficient in the case of fresh, unprocessed meat. Thus, researchers are looking for non-thermal technologies that will inactivate or inhibit growth of microbiota while maintaining meat quality (Zhou et al. 2010).

Many studies indicate that cold plasma treatment may be employed for the preservation of food (Moreau et al. 2008; Song et al. 2009; Kim et al. 2011). Cold plasma as an ionized gas contains UV photons, neutral atoms and molecules, excited atoms and molecules, electrons and free radicals (Moreau et al. 2008). Those plasma species are involved in the inactivation process by interacting with bacterial cells, causing: damage to DNA by UV irradiation (living cells cannot repair lesions of the DNA strands sufficiently quickly); erosion of the microorganism through intrinsic photodesorption (formation of volatile compounds due to breakages of chemical bonds in microbial material) and through etching involving free radicals (Moisan et al. 2002). Low-pressure plasma techniques have various advantages for use in the meat industry. They are environmentally friendly and work at low temperatures, so thermolabile products can be treated. The other benefit relates to the fact that plasma treatments can be applied to large areas (limited by vacuum chamber size), and can be distributed evenly inside the chamber so the whole surface of the material is treated uniformly. On the other hand, vacuum systems are expensive, thus economic aspects need to be considered (Schütze et al. 1998).

The aim of this study was to investigate antimicrobial activity of low-pressure argon and helium plasma treatment against bacterial species generally encountered in meat spoilage as well as against surface microbiota of pork and beef muscles.

\section{Materials and methods}

Antimicrobial activity

\section{Pure bacterial cultures}

Five strains of Gram-positive and three Gram-negative bacteria were selected as test organisms: Microccocus luteus PCM 1944, Lactobacillus acidophilus PCM 2510, Bacillus subtilis PCM 2021 (vegetative forms), Staphylococcus aureus PCM 2602, Listeria monocytogenes PCM 2606, Escherichia coli PCM 2560, Yersinia enterocolitica PCM 2080, and Pseudomonas fluorescens PCM 1994. These microorganisms were obtained from the culture collections of Institute of Immunology and Experimental Therapy, Polish Academy of Sciences. The bacteria selected are frequently reported in the literature as responsible for meat and meat product spoilage (Dave and Ghaly 2011).

Antibacterial activity was assessed using the plate method. P. fluorescens, B. subtilis, S. aureus, E. coli, and Y. enterocolitica inoculum were prepared by growing cells in enriched broth containing beef broth, peptone, sodium chloride, peptone $\mathrm{C}$, yeast extract (BTL, Lodz, Poland) for $24 \mathrm{~h}$ at $37{ }^{\circ} \mathrm{C}$ and at $25^{\circ} \mathrm{C}$ for M. luteus. Lactobacillus acidophilus were grown in MRS broth (Merck, Warsaw, Poland) at $37{ }^{\circ} \mathrm{C}$ and Listeria monocytogenes in BHI broth (Merck) at $30^{\circ} \mathrm{C}$. Optical density of bacterial cultures was measured using a spectrophotometer UV 1800 (Rayleigh Instruments, Rayleigh, UK) at $550 \mathrm{~nm}$. Enumeration of bacteria in control samples was determined using the viable plate count method. Inoculum containing $10^{4} \mathrm{CFU} / \mathrm{ml}$ was diluted $(1: 10,1: 100)$ and $0.1 \mathrm{~mL}$ of final two dilutions was transferred to duplicate nutrient agar plates. The number of CFU/ $\mathrm{mL}$ in the control sample can then be determined by multiplying the number of colonies on a dilution plate by the corresponding dilution factor. Only plates (or replicate plates from the same dilution) with 30-300 colonies were counted.

Plates that had been seeded previously with $0.1 \mathrm{~mL}$ inoculum containing $10^{4} \mathrm{CFU} / \mathrm{mL}$ test bacteria were exposed to helium and argon plasma treatment for 2, 5 and $10 \mathrm{~min}$ at low pressure $(20 \mathrm{kPa})$ and then incubated as noted above. Initial populations in control samples were about $10^{3} \mathrm{CFU} / \mathrm{mL}$. Results are expressed as log reduction and were calculated as shown in following equation:

Logreduction $=\log _{10}\left(N_{0}\right)-\log _{10}(N)$

where,

$\mathrm{N}_{0}$ is the number of viable microorganisms before treatment (initial population)

$\mathrm{N}$ the number of viable microorganisms after treatment.

\section{Plasma treatments and microbial analysis of raw meat}

Fresh pork longissimus dorsi muscle ( $24 \mathrm{~h}$ post mortem) and beef musculus semitendinosus muscle ( $48 \mathrm{~h}$ post mortem) were purchased from a local meat processing plant (Dworecki, Poland). The surface layers of muscle (thickness $2 \mathrm{~cm}$, length $7 \mathrm{~cm}$, width $7 \mathrm{~cm}$ ) were cut out and exposed to helium and argon cold plasma for 2, 5 and $10 \mathrm{~min}$ at low pressure $(20 \mathrm{kPa})$. The experiments were conducted in triplicate, using the same meat batch for each one. These samples were compared to samples not subjected to cold plasma treatment. Temperature of meat samples was measured immediately before and after low-pressure plasma treatment. The average temperature of untreated sample was $4.1{ }^{\circ} \mathrm{C}$ and increased to $7.0^{\circ} \mathrm{C}$ after $10 \mathrm{~min}$ exposure. Sampling was started immediately after low-pressure plasma exposure. Sterile cotton swabs were used for surface sampling in accordance with ISO 18593:2004 ${ }^{1}$.

\footnotetext{
${ }^{1}$ ISO 18593:2004. Microbiology of food and animal feeding stuffs. Horizontal methods for sampling techniques from surfaces using contact plates and swabs
} 
The swab head was moistened with sterile saline solution and excessive solution was pressed out against the interior wall of the vial with a rotating motion. A template with a $5 \mathrm{~cm} \times 5 \mathrm{~cm}$ opening was used to sample the same surface area each time. After the area has been swabbed, the swab head was placed in the vial and series of dilutions were prepared (ISO $17604: 2003)^{2}$. Determination of total number of microorganisms (TNM) was done using the plate method described in ISO $2293: 1988^{3}$. Colonies were counted after $72 \mathrm{~h}$ of incubation at $30{ }^{\circ} \mathrm{C}$ on culture medium containing tryptone (BTL), yeast extract (Merck), glucose (BTL) and agar (Merck). Psychrotrophic microorganisms (P) were determined on PCA plates (hydrolyzed casein (BTL), yeast extract, glucose, and agar incubated at $6{ }^{\circ} \mathrm{C}$ for 10 days (ISO 17410:2001) ${ }^{4}$. Culture medium of yeast and mold (Y\&M) was prepared using yeast extract, glucose, agar and was supplemented with antibiotic (chloramphenicol) (Sigma-Aldrich, Poland). Plates were incubated for 5 days at $25^{\circ} \mathrm{C}$ (ISO 21527-1:2008). The CFU per milliliter of each sample was calculated as shown in the following equation:

$N=\sum C /\left\{\left(n_{1} \times 1\right)+\left(n_{2} \times 0.1\right)\right\} d$

where,

$\mathrm{N}$ is the number of colonies per milliliter of the product $(\mathrm{CFU} / \mathrm{ml})$

$\sum \mathrm{C}$ is the sum of all colonies in all plates counted

$\mathrm{n}_{1}$ is the number of plates in lower dilution counted

$\mathrm{n}_{2}$ the number of plates higher dilution counted

$\mathrm{d}$ is the dilution level corresponding to first count $\left(\mathrm{n}_{1}\right)$

The CFU per square centimeter were calculated using the following formula:

$N_{s}=(N \times F) / A$

where,

$\mathrm{N}$ is the number of colonies per milliliter of product (CFU/mL)

$\mathrm{F}$ is the amount $(\mathrm{mL})$ of dilution fluid

$\mathrm{A}$ is the surface investigated $\left(\mathrm{cm}^{2}\right)$.

$\overline{2}$ ISO 17604:2003 Microbiology of food and animal feeding stuffs. Carcass sampling for microbiological analysis

${ }^{3}$ ISO 2293:1988 Meat and meat products. Enumeration of microorganisms. Colony count technique at $30^{\circ} \mathrm{C}$

${ }^{4}$ ISO 17410:2001 Microbiology of food and animal feeding stuffs. Horizontal method for the enumeration of psychrotrophic microorganisms

${ }^{5}$ ISO 21527-1:2008 Microbiology of food and animal feeding stuffs. Horizontal method for the enumeration of yeasts and moulds. Part1: colony count technique in products with water activity greater than 095
The results are expressed as log reduction and were calculated according to Eq (1) above.

\section{Low-pressure cold plasma treatment}

The laboratory pulsed plasma reactor (Ertec Poland, Wrocław, Poland) used in this experiment is shown in Fig. 1. Cold plasma was generated by high voltage discharge in a vacuum chamber (diameter $250 \mathrm{~mm}$, height $500 \mathrm{~mm}$, vacuum $100 \mathrm{~Pa}$ ) between the electrodes of the discharge condenser located on a high voltage table, where the sample was placed in glow position. The electrodes were made of quartz frits and the distance between them was $5 \mathrm{~cm}$. Running pressure was 20 $\mathrm{kPa}$. Gas flow was set at $3 \mathrm{~L} / \mathrm{min}$. The frequencies used for the alternating voltages were between 20 and $100 \mathrm{kHz}$ and reactive power was $1.2 \mathrm{kVA}$. In contrast to atmospheric cold plasma, low-pressure plasma could be used in the meat industry due to its advantageous properties such as the ability to treat large areas, even distribution in the vacuum chamber, uniformity of treatment and low process temperature.

\section{Scanning electron microscopy}

Escherichia coli was grown in enriched broth for $24 \mathrm{~h}$ at $37^{\circ} \mathrm{C}$ and then centrifuged at $5,000 \mathrm{~g}$ for $15 \mathrm{~min}$. After centrifugation, the aqueous phase layer was collected and the pellet of bacterial culture obtained was removed to a cover glass and then exposed to helium and argon plasma for 2, 5 and $10 \mathrm{~min}$ according as described above. The control sample was not subjected to cold plasma treatment. Bacterial pellets were

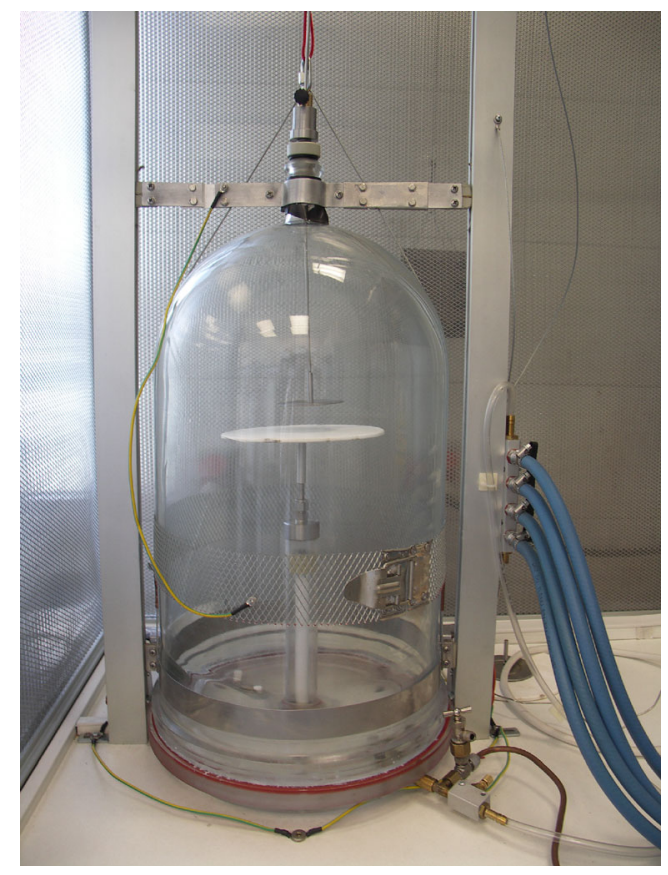

Fig 1 Prototype generator of cold plasma 
stored on cover glasses in $2.5 \%$ glutaraldehyde overnight. SEM was used to investigate the cell structure of $E$. coli and examination was performed according to the protocol described by Kaliński et al. (2012).

\section{Statistical analysis}

Each experiment was replicated three times and plate count analyses were made in quadruplicate for each sample (three independent experiments analyzed in quadruplicate). The effect of two independent categorical variables, such as time of exposure and type of gas being used, was evaluated. Data were analyzed by two-way factor analysis of variance (ANOVA) using Statistica 9 (StatSoft, Krakow, Poland). Differences between mean values were identified by Duncan's test with a confidence level at $P<0.05$.

\section{Results and discussion}

\section{Antimicrobial activity}

The effect of argon and helium plasma treatment on reduction of meat microbiota numbers is presented in Table 1. TNM, $\mathrm{Y} \& \mathrm{M}$ and $\mathrm{P}$ were initially around values of $4.96-5.23,3.14$ $3.55,3.65-4.13 \mathrm{CFU} / \mathrm{cm}^{2}$ respectively in both pork and beef muscles. The logarithmic reductions depend on time of exposure and type of gas being used. The highest inactivation efficiency was observed for helium plasma treatment. Y\&M, TNM and P from pork muscle were reduced respectively about 1.90, 1.14, and $1.60 \log$ cycle after 10 min exposure. Usage of argon plasma resulted in lower reduction of pork microbiota and was respectively $0.41,0.77$ and $1.20 \mathrm{log}$ in the same time of treatment. It was also observed that TNM from beef were reduced of about 1.00 and $2.10 \log$ after 5 and $10 \mathrm{~min}$, respectively. These results indicate that increasing exposure time from 2 to 10 min significantly enhance decontamination effect of cold plasma treatment.

Different microorganisms showed variable sensitiveness to cold plasma treatments when inoculated onto the surface of agarized media (Tables 2, Table 3). Treatments resulted in reduction of tested bacteria counts except for Listeria monocytogenes ranging from 0.34 to $2.00 \mathrm{log}$ orders of magnitude from an initial population of $10^{3} \mathrm{CFU} / \mathrm{mL}$. The bacterium most susceptible to plasma exposure was B. subtilis. After 2 min of exposure a significant reduction of population of about $2.00 \mathrm{log}$ was observed. After $5 \mathrm{~min}$ of exposure, helium plasma reduced E. coli and Y. enterocolitica by about $2.00 \mathrm{log}$. Similar results were obtained with argon plasma after $10 \mathrm{~min}$. The $P$. fluorescens population was reduced by about $0.38 \log$ using helium plasma for $5 \mathrm{~min}$. A longer time of exposure caused a $1.97 \mathrm{log}$ reduction of those bacteria. For argon plasma, a significant inactivation effect was also achieved within $10 \mathrm{~min}$ but the log reduction was lower $(0.63 \log )$.

No significant differences in Listeria monocytogenes counts were noted between the control sample and samples treated with helium and argon plasma. Lactobacillus acidophilus showed similar resistance against argon plasma but use of helium enabled a significant reduction of more than $0.50 \mathrm{log}$ after $5 \mathrm{~min}$. The results clearly indicate that helium plasma treatment is more effective than argon plasma in inactivation of microorganisms if comparing the same time of exposure. Although an antimicrobial activity of cold plasma was confirmed, in some cases the use of other methods of decontamination to enhance microbiological safety of meat seems justified. Combination of food preservation methods is known as hurdle technology and was described by Leistner and Gould (2002). Previous study has proved the antibacterial activities of chitosan films, therefore application of low-pressure plasma combined with edible coatings and/or films may be more efficient in food preservation as well as reducing the physical changes in fresh products (Ulbin-Figlewicz et al. 2014).

Table 1 Effect of cold plasma treatment on surface microbiota of meat. Values with different letters (a-e) within the same column differ significantly $(P<0.05)$. TNM Total number of microorganisms, $Y \& M$ yeasts and molds, $P$ psychrotrophic microorganisms

\begin{tabular}{|c|c|c|c|c|c|c|c|}
\hline \multirow[t]{3}{*}{ Type of plasma } & \multirow[t]{3}{*}{ Exposure time (min) } & \multicolumn{6}{|l|}{ Log reduction } \\
\hline & & \multicolumn{2}{|l|}{ TNM } & \multicolumn{2}{|l|}{ Y\&M } & \multicolumn{2}{|l|}{$\mathrm{P}$} \\
\hline & & Pork & Beef & Pork & Beef & Pork & Beef \\
\hline \multirow[t]{3}{*}{ Helium } & 2 & $0.79 \pm 0.10 \mathrm{c}$ & $0.55 \pm 0.09 \mathrm{~b}$ & $0.38 \pm 0.11 \mathrm{~b}$ & $0.25 \pm 0.04 \mathrm{~b}$ & $0.60 \pm 0.10 \mathrm{~b}$ & $0.19 \pm 0.02 \mathrm{a}$ \\
\hline & 5 & $0.94 \pm 0.05 \mathrm{~d}$ & $1.01 \pm 0.03 \mathrm{c}$ & $0.60 \pm 0.19 \mathrm{~b}$ & $0.50 \pm 0.06 \mathrm{c}$ & $0.81 \pm 0.16 \mathrm{~b}$ & $0.73 \pm 0.21 \mathrm{~b}$ \\
\hline & 10 & $1.14 \pm 0.03 \mathrm{e}$ & $2.09 \pm 0.04 \mathrm{~d}$ & $1.90 \pm 0.02 \mathrm{c}$ & $0.98 \pm 0.02 \mathrm{~d}$ & $1.60 \pm 0.02 \mathrm{~d}$ & $1.48 \pm 0.09 \mathrm{c}$ \\
\hline \multirow[t]{3}{*}{ Argon } & 2 & $0 \pm 0.01 \mathrm{a}$ & $0.16 \pm 0.08 \mathrm{a}$ & $0 \pm 0.01 \mathrm{a}$ & $0.04 \pm 0.01 \mathrm{a}$ & $0.14 \pm 0.02 \mathrm{a}$ & $0.23 \pm 0.19 \mathrm{a}$ \\
\hline & 5 & $0.34 \pm 0.05 \mathrm{~b}$ & $0.57 \pm 0.06 \mathrm{~b}$ & $0.40 \pm 0.9 \mathrm{~b}$ & $0.28 \pm 0.09 \mathrm{~b}$ & $0.50 \pm 0.11 \mathrm{~b}$ & $0.70 \pm 0.30 \mathrm{~b}$ \\
\hline & 10 & $0.77 \pm 0.08 \mathrm{c}$ & $0.56 \pm 0.05 \mathrm{~b}$ & $0.41 \pm 0.8 \mathrm{~b}$ & $0.50 \pm 0.03 \mathrm{c}$ & $1.20 \pm 0.01 \mathrm{c}$ & $1.32 \pm 0.10 \mathrm{c}$ \\
\hline
\end{tabular}


Table 2 Effect of cold plasma treatment on Gram-positive bacteria inoculated onto the surface of agarized medium. Values with different letters (a-c) within the same column differ significantly $(P<0.05)$

\begin{tabular}{|c|c|c|c|c|c|c|}
\hline \multirow[t]{2}{*}{ Type of plasma } & \multirow{2}{*}{$\begin{array}{l}\text { Exposure } \\
\text { time (min) }\end{array}$} & \multicolumn{5}{|l|}{ Log reduction } \\
\hline & & Bacillus subtilis & Micrococcus luteus & Staphylococcus aureus & Listeria monocytogenes & Lactobacillus acidophilus \\
\hline \multirow[t]{3}{*}{ Helium } & 2 & $1.92 \pm 0.08 \mathrm{~b}$ & $0.52 \pm 0.21 \mathrm{~b}$ & $0.64 \pm 0.30 \mathrm{~b}$ & $0 \pm 0.01 \mathrm{a}$ & $0.20 \pm 0.02 \mathrm{a}$ \\
\hline & 5 & $2.00 \pm 0.05 \mathrm{~b}$ & $1.06 \pm 0.11 \mathrm{c}$ & $1.98 \pm 0.04 \mathrm{c}$ & $0.06 \pm 0.02 \mathrm{a}$ & $0.53 \pm 0.11 \mathrm{~b}$ \\
\hline & 10 & $1.97 \pm 0.05 \mathrm{~b}$ & $1.48 \pm 0.09 \mathrm{c}$ & $2.02 \pm 0.07 \mathrm{c}$ & $0.11 \pm 0.07 \mathrm{a}$ & $0.69 \pm 0.08 \mathrm{~b}$ \\
\hline \multirow[t]{3}{*}{ Argon } & 2 & $1.79 \pm 0.18 \mathrm{~b}$ & $0.01 \pm 0.01 \mathrm{a}$ & $0.08 \pm 0.05 \mathrm{a}$ & $0 \pm 0.00 \mathrm{a}$ & $0 \pm 0.00 \mathrm{a}$ \\
\hline & 5 & $1.98 \pm 0.05 \mathrm{~b}$ & $0.34 \pm 0.09 \mathrm{~b}$ & $0.88 \pm 0.12 \mathrm{bc}$ & $0 \pm 0.01 \mathrm{a}$ & $0 \pm 0.01 \mathrm{a}$ \\
\hline & 10 & $2.00 \pm 0.07 \mathrm{~b}$ & $0.89 \pm 0.12 \mathrm{c}$ & $0.96 \pm 0.16 \mathrm{bc}$ & $0.09 \pm 0.05 \mathrm{a}$ & $0.17 \pm 0.1 \mathrm{a}$ \\
\hline
\end{tabular}

According to Moisan et al. (2002), UV radiation and erosion processes provide a mechanism of cold plasma sterilization. Inactivation of the DNA and RNA or etching of cell wall/ membrane is affected by UV radiation, especially in lowpressure plasma because the content of UV photons can be considerable. Erosion can be attributed to the etching activity of radicals and charged particles (Moisan et al. 2002). Lowpressure plasma decontamination processes use non-toxic gas mixtures (for instance $\mathrm{Ar}, \mathrm{H}_{2}, \mathrm{O}_{2}, \mathrm{~N}_{2}$ etc.) (Rossi et al. 2008). Depending on the process gas, various chemically reactive species are generated and these show different effects on microorganisms (Fricke 2012). The sterilization effectiveness of helium and argon plasma may be attributed to the fact that the ionization potential of helium $(24.6 \mathrm{eV})$ is higher than that of argon $(15.8 \mathrm{eV})$. In contrast to helium, argon plasma does not generate substantial quantities of elements possessing high ionization energies (Okino et al. 1996). In addition, noble gas plasmas produce very intense UV radiation, especially in the helium plasma (Weidner et al. 1998). Radicals could cause etching of the cell wall/membrane, oxidation of proteins, DNA, RNA and enzymes, while charged particles cause etching, perforation of the cell wall and electroporation. Pulses of electric field could also lead to irreversible damage to membranes (Fricke 2012). The lifetime of the mentioned reactive species at reduced pressure is much longer in comparison to atmospheric plasma (Shintani et al. 2010).

A high resistance of $B$. subtilis to a variety of treatments, including heat, UV radiation, and oxidizing agents such as hydrogen peroxide, has been reported by many authors (Setlow 2006; Hanlin et al. 1985; Popham et al. 1995). Despite the fact that bacterial spores are more resistant than vegetative cells to physical and chemical treatments, destroying spores by exposure to low-pressure plasma is possible as a result of UV photons passing through the spore-protecting coats and damaging the DNA within (Moisan et al. 2002; Rossi et al. 2008). However, erosion of the spore surface as an additional mechanism must be provided to make it easier for the photons to reach the DNA (Moisan et al. 2002). von Kuedell et al. (2010) observed that spores of Bacillus atrophaeus were reduced by at least four orders of magnitude under optimized low-pressure argon plasma. Lerouge et al. (2000) indicated that spore mortality depends on plasma gas compositions $\left(\mathrm{O}_{2}, \mathrm{O}_{2} / \mathrm{Ar}, \mathrm{O}_{2} / \mathrm{H}_{2}, \mathrm{CO}_{2}\right.$, and $\mathrm{O}_{2} /$ $\mathrm{CF}_{4}$ ). The highest efficiency was seen with $\mathrm{O}_{2} / \mathrm{CF}_{4}$ plasma, giving a $5 \log$ decrease within $7.5 \mathrm{~min}$. These latter authors also indicated that etching contributes to spore mortality. Similar results were obtained by Roth et al. (2009), who indicated that $B$. subtilis spores are inactivated efficiently by

Table 3 Effects of cold plasma treatment on Gram-negative bacteria inoculated onto the surface of agarized medium. Values with different letters (a-c) within the same column differ significantly $(P<0.05)$

\begin{tabular}{lllll}
\hline Type of plasma & Exposure time $(\mathrm{min})$ & \multicolumn{2}{l}{ Log reduction } & \\
\cline { 3 - 5 } & & Escherichia coli & Yersinia enterocolitica & Pseudomonas fluorescens \\
\hline Helium & 2 & $0.44 \pm 0.13 \mathrm{~b}$ & $1.98 \pm 0.02 \mathrm{c}$ & $0.01 \pm 0.01 \mathrm{a}$ \\
& 5 & $1.99 \pm 0.04 \mathrm{c}$ & $1.97 \pm 0.04 \mathrm{c}$ & $0.38 \pm 0.13 \mathrm{~b}$ \\
Argon & 10 & $2.01 \pm 0.02 \mathrm{c}$ & $2.00 \pm 0.01 \mathrm{c}$ & $0.97 \pm 0.06 \mathrm{c}$ \\
& 5 & $0.01 \pm 0.01 \mathrm{a}$ & $0.34 \pm 0.09 \mathrm{~b}$ & $0.01 \pm 0.00 \mathrm{a}$ \\
& 10 & $0.49 \pm 0.11 \mathrm{~b}$ & $1.12 \pm 0.07 \mathrm{c}$ & $0.63 \pm 0.14 \mathrm{~b}$ \\
\hline
\end{tabular}


a combination of protein inactivation and DNA damage due to the dominant role of UV radiation and erosion processes.

Gram-positive bacteria are more resistant than Gramnegative bacteria due to differences in cell-wall structure. Thus, longer treatment times may be necessary to damage the outer cell membrane of Gram-positive bacteria and cause cell lysis (Weltmann et al. 2012). Purevdorj et al. (2002) found that growth of $E$. coli was reduced by about 4.47, 5.19 and $6.29 \mathrm{log}$ cycle after $30 \mathrm{~min}$ of argon plasma treatment with increasing microwave power density in the range of 1.47, 2.63 and $4.21 \mathrm{w} / \mathrm{cm}^{3}$, respectively. A high sensitivity of $E$. coli to $\mathrm{N}_{2} \mathrm{O}$ plasma treatment was observed by Chau et al. (1996); the time required for killing those bacteria is $2 \mathrm{~min}$. Chau et al. (1996) also found that $P$. fluorescens exhibits the greatest resistance to treatment, with the time of inactivation being 10 min (Chau et al. 1996). In the last few years, atmospheric pressure plasmas have been the object of many investigations. Kim et al. (2011) observed reduction of Listeria monocytogenes, E. coli and Salmonella typhimurium on sliced bacon treated with helium and helium/oxygen plasmas of about 1-2 log cycles and 2-3 log cycles, respectively. Inactivation of $E$. coli on almonds, apples, pork has also between described by other authors (Deng et al. 2007; Niemira and Sites 2008; Moon et al. 2009). Despite these promising results, the implementation of atmospheric plasma in the meat industry is limited due to the small area that can be targeted for treatment. Depending on the experimental parameters of cold plasma treatment, the antibacterial effect is different. Rossi et al. (2008) investigated the effect of lowpressure plasma on depyrogenation of bacterial endotoxins such as lipopolysaccharides (LPS), which constitute a major part of the outer cell wall of Gram-negative bacteria. After 5 min exposure, a significant reduction in LPS bioactivity of about 2 orders of magnitude was observed. These authors also indicated that the efficiency of depyrogenation of LPS and Lipid A was accelerated significantly by the enhancement of hydrogen content in the plasma gas mixture. Selcuk et al. (2008) observed a significant reduction of $3 \log$ for both Aspergillus spp. and Penicillium spp. artificially contaminated on seed surfaces within 15 min of $\mathrm{SF}_{6}$ plasma treatment time. Inactivation of these pathogenic fungi depends on seed surface, plasma gas type, plasma treatment time, and microbial population density. Seed quality was not affected by air and $\mathrm{SF}_{6}$ plasma treatment. The percentage germination rate of wheat or bean seeds treated with low-pressure plasma did not differ significantly compared to an untreated sample. According to Pignata et al. (2014), both oxygen and argon low-pressure plasma caused a reduction of Aspergillus brasiliensis of about $3.5 \mathrm{log}$ cycles after $30 \mathrm{~min}$ of exposure, while a mixture of both gases resulted in a $5.4 \mathrm{log}$ reduction. For the reduction of E. coli, a shorter time of treatment was required because of its higher sensitivity to cold plasma. Treatment for
$30 \mathrm{~s}$ and $60 \mathrm{~s}$ resulted in a $4 \log$ reduction with argon and oxygen plasma, respectively.

Lerouge et al. (2001) indicated gas composition as a determining factor in the effectiveness of plasma. Gas flow rate and pressure, the type of generator design and power, all play an important role as well. Higher electron and ions density caused by rising power, in synergy with ultraviolet photons, led to better destruction of bacterial cells (Bol'shakov et al. 2004). On the other hand, issues related to treated material need to be taken into consideration. Packaging, the nature and quantity of substrates, and the temperature and nature of microorganisms are highly relevant to the decontamination effect (Lerouge et al. 2001).

One of the major sources of food contamination and clinical infection are pathogens able to form biofilms. This is a complex process in which genetic mechanisms and the properties of both substratum and bacterial cell surfaces, as well as environmental factors, are involved (Shi and Zhu 2009). The relationship between stress and biofilm formation was confirmed by Zhang et al. (2007). They indicated that E. coli produce more biofilm in response to adverse environmental conditions such as acidic $\mathrm{pH}$, oxidative stress $\left(\mathrm{H}_{2} \mathrm{O}_{2}\right)$, heavy metals [Cd(II)], and cold shock $\left(22^{\circ} \mathrm{C}\right)$. Surface structures of bacteria such as flagella, pili and curli are used to initiate biofilm formation (Pratt and Kolter 1998; Zhang et al. 2007). Because of the different properties of biofilms, resistance to conventional sterilization methods is higher. In addition, usage of chemical compounds (e.g., ethylene oxide or chlorine), high temperature and radiation have some limitations relating to thermolabile products or human health. Scientists are looking for new methods to biofilm inactivation, and cold plasma technology could be one of them (BrellesMariño 2012). Therefore investigation into the effect of low-pressure plasma on biofilm inactivation needs to be considered in future.

\section{Scanning electron microscopy}

Scanning electron microscopy (SEM) was used to examine morphological changes of E. coli bacteria exposed to cold plasma treatments (Fig. 2). Argon and helium plasmas treatment for 2 min caused shrinkage in a bacterial cell wall, suggesting a bacteriostatic effect. A bactericidal effect was evidenced, since lysis of cells subjected to helium plasma was observed (Fig. 2d). Some of the cells were completely destroyed and, as a result, a bactericidal effect was noted. Disruption of $E$. coli cells exposed to argon plasma for 10 min was also observed. These changes in the morphological structure of the cell indicate that argon plasma treatment induces lysis, but we are still an early stage in this field. SEM results are in agreement with microbiological analysis. Reduction in the log counts of the microbes subjected to 

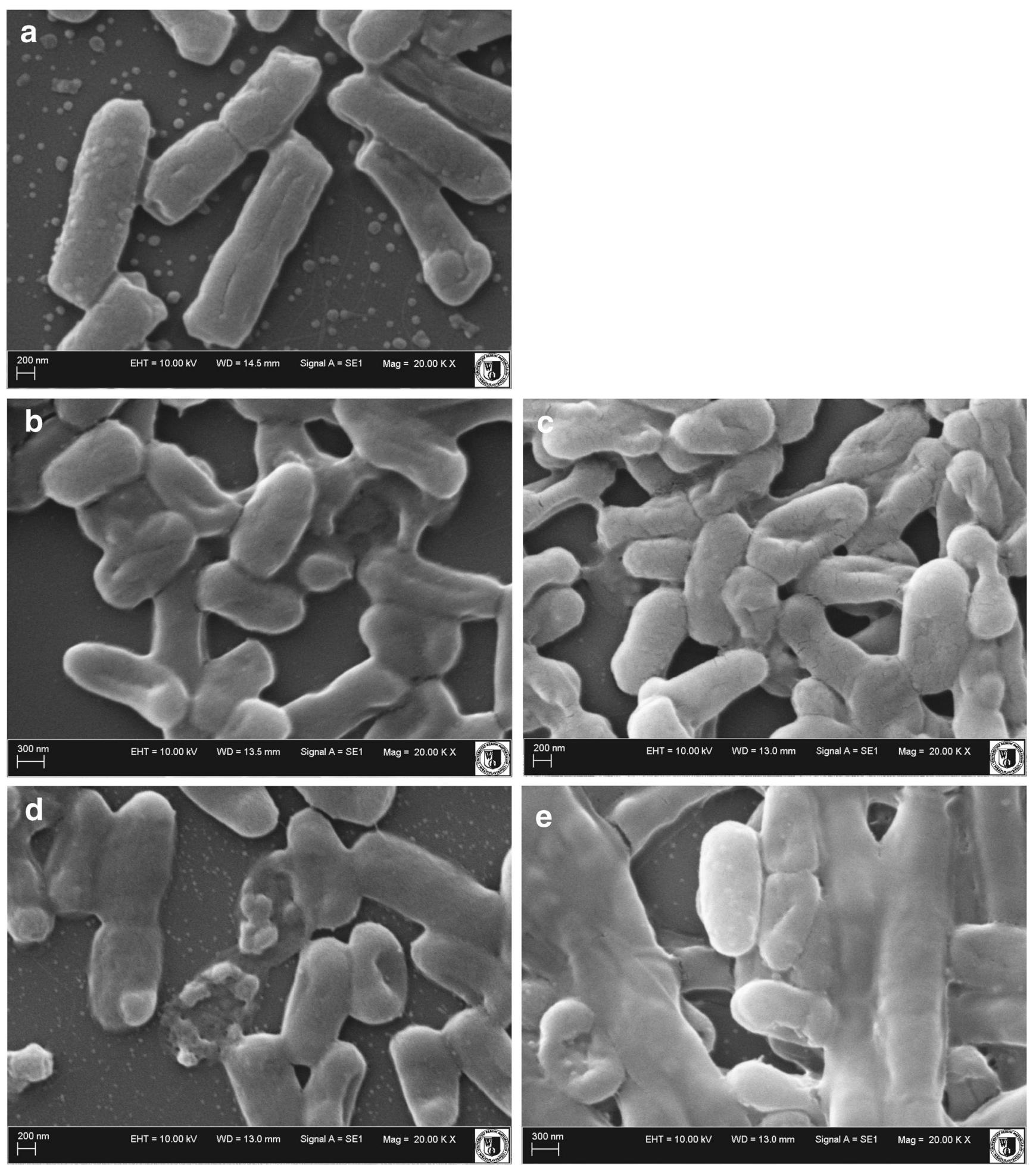

Fig 2a-e Scanning electron microscopy (SEM) images of Escherichia coli. a Untreated control. b After helium plasma exposure for 2 min. c After argon plasma exposure for $2 \mathrm{~min}$. d After helium plasma exposure for $10 \mathrm{~min}$. e After argon plasma exposure for $10 \mathrm{~min}$

treatment increases with increased exposure time, because damage to bacterial cells is greater.

Hong et al. (2009) observed severe cytoplasmic deformations and leakage of the bacterial chromosome in cells treated with atmospheric plasma. Disruptions and cell lysis of E. coli exposed to Ar-NO plasma treatment was also demonstrated by Hueso et al. (2008).

Untreated E. coli cells appeared intact and separated from each other (Fig. 3a), while bacterial cells treated with lowpressure plasma appeared to be aggregated (Fig. 3b,e). It can 

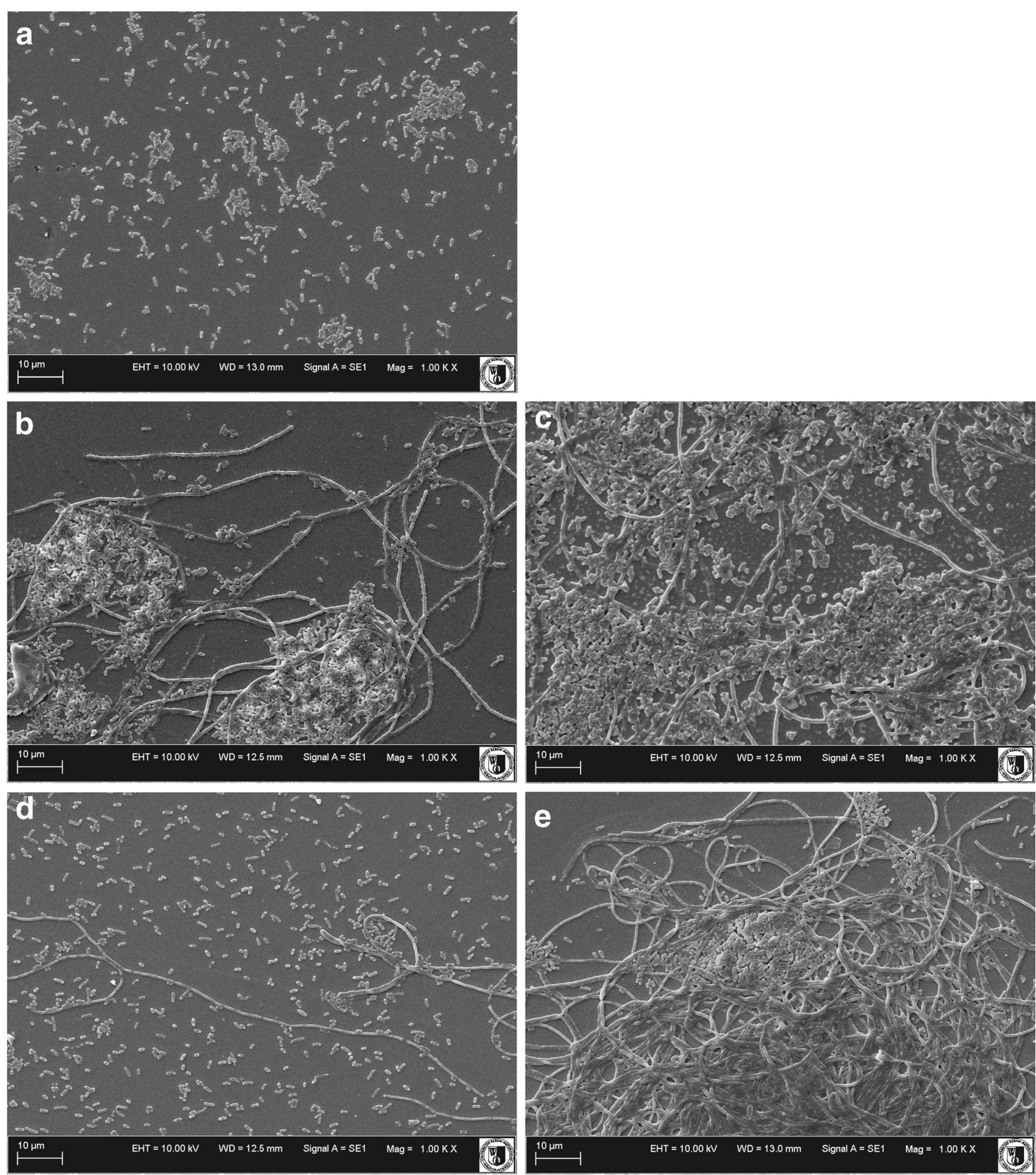

Fig. 3 SEM images of aggregated cells of Escherichia coli. a Untreated control. b After helium plasma exposure for 2 min. c After argon plasma exposure for $2 \mathrm{~min}$. d After helium plasma exposure for $10 \mathrm{~min}$. e After argon plasma exposure for $10 \mathrm{~min}$

be hypothesized that the observed differences are caused by modification of the surface properties of cells exposed to plasma treatment. The aggregation of bacterial cells as a response to stress due to antibacterial agents was also reported by other authors. Tyagi and Malik (2012) observed morphological alterations in E. coli cells treated with lemon grass oil. They reported that cytoplasmic material of the bacterial cells had leaked and the aggregate cells appeared as sludge. According to Tang et al. (2007), both E. coli and Shewanella oneidensis aggregated after addition of $\mathrm{C}_{60}-\mathrm{NH}_{2}$ 
(fullerene compound). They indicated that aggregation was associated with oxidative stress and could represent protection mechanism.

\section{Conclusions}

The results of this study showed the effectiveness of lowpressure plasma treatment for decontamination of meat. Use of helium plasma results in a higher reduction of microbes compared to argon plasma treatment. Loss of viability of bacteria is explained by serious damage to cell morphology. The effectiveness of cold plasma varies with experimental parameters, the subject material and the nature of the microorganism. The results suggest that application of low-pressure plasma is a promising treatment for inactivation of surface microbiota of meat.

Acknowledgment These experiments were carried out in the frame of development project No N R12 0079 06/2009 "Development of methods to improve the quality and safety of refrigerated and stored meat" funded by Scientific Research and Development Center.

Open Access This article is distributed under the terms of the Creative Commons Attribution License which permits any use, distribution, and reproduction in any medium, provided the original author(s) and the source are credited.

\section{References}

Bol'shakov AA, Cruden BA, Mogul R, Rao MVS, Sharma SP, Khare BN, Meyyappan M (2004) Radio-frequency oxygen plasma as sterilization source. AIAA Journal 42:823-832

Borch E, Nesbakken T, Christensen H (1996) Hazard identificationin swine slaughter with respect to foodborne bacteria. Int J Food Microbiol 30:9-25

Brelles-Mariño G (2012) Challenges in biofilm inactivation: the use of cold plasma as a new approach. J Bioprocess Biotech 2:2-5

Chau TT, Kao KC, Blank G, Madrid F (1996) Microwave plasma for low-temperature dry sterilization. Biomaterials 17:1273-1277

Dave D, Ghaly AE (2011) Meat spoilage mechanisms and preservation techniques: a critical review. Am J Agric Biol Sci 6:486-510

Deng S, Ruan R, Mok CK, Huang G, Lin X, Chen P (2007) Inactivation of Escherichia coli on almonds using nonthermal plasma. J Food Sci $72: 62-66$

Fricke K (2012) Influence of non-thermal plasma-based biological decontamination processes on the surface properties of plasmaexposed polymers. http://d-nb.info/1030246211/34 Accessed 7 August 2014

Hanlin JH, Lombardi SJ, Slepecky RA (1985) Heat and UV light resistance of vegetative cells and spores of Bacillus subtilis rec- mutants. J Bacteriol 163:774-777

Hong YF, Kang JG, Lee HY, Uhm HS, Moon E, Park YH (2009) Sterilization effect of atmospheric plasma on Escherichia coli and Bacillus subtilis endospores. Lett Appl Microbiol 48:33-37
Hueso JL, Rico VJ, Frias JE, Cotrino J, Gonzalez-Elipe AR (2008) Ar+ NO microwave plasmas for Escherichia coli sterilization. J Phys D Appl Phys 41:1-4

Kaliński K, Marycz K, Czogała J, Serwa E, Janeczek W (2012) An application of scanning electron microscopy combined with roentgen microanalysis (SEM-EDS) in canine urolithiasis. J Electron Microsc 61:47-55

Kanerva M (2013) Meat consumption in Europe: issues trends and debates. Artec, Bremen

Kim B, Yun H, Jung S, Jung Y, Jung H, Choe W, Jo C (2011) Effect of atmospheric pressure plasma on inactivation of pathogens inoculated onto bacon using two different gas compositions. Food Microbiol 28:9-13

Leistner L, Gould GW (2002) Hurdle technologies: combination treatments for food stability safety and quality. Plenum, New York

Lerouge S, Wertheimer MR, Marchand R, Tabrizian M, Yahia LH (2000) Effect of gas composition on spore mortality and etching during low-pressure plasma sterilization. J Biomed Mater Res 51:128-135

Lerouge S, Wertheimer MR, Yahia L'H (2001) Plasma sterilization: a review of parameters mechanisms and limitations. Plasmas Polym 6: $175-188$

Moisan M, Barbeau J, Crevier MC, Pelletier J, Philip N, Saoudi B (2002) Plasma sterilization. Methods and mechanisms. Pure Appl Chem 3: 349-358

Moon SY, Kim DB, Gweon B, Choe W, Song HP, Yo C (2009) Feasibility study of the sterilization of pork and human skin surfaces by atmospheric pressure plasmas. Thin Solid Films 14:4272-4275

Moreau M, Orange N, Feuilloley MGJ (2008) Non-thermal plasma technologies: new tools for bio-decontamination. Biotech Adv 26: 610-617

Niemira BA, Sites J (2008) Cold plasma inactivates Salmonella Stanley and Escherichia coli O157:H7 inoculated on golden delicious apples. J Food Protect 71:1357-1365

Okino A, Ishizuka H, Hotta E, Shimada R (1996) Production of helium ICP-MS system for detection of higher ionization energy elements. IEEE International Conference on Plasma Science. doi:10.1109/ PLASMA.1996.550934

Pignata C, Angelo DD, Basso D, Cavallero MC, Beneventi S, Tartaro D, Meineri V, Gili G (2014) Low-temperature, low-pressure gas plasma application on Aspergillus brasiliensis, Escherichia coli and pistachios. J Appl Microbiol 116:1137-1148

Popham DL, Sengupta S, Setlow P (1995) Heat, hydrogen peroxide, and uv resistance of Bacillus subtilis spores with increased core water content and with or without major dna-binding proteins. Appl Environ Microbiol 61:3633-3638

Pratt LA, Kolter R (1998) Genetic analysis of Escherichia coli biofilim formation: roles of flagella motility chemotaxis and type I pili. Mol Microbiol 30:285-293

Purevdorj D, Igura N, Hayakawa I, Ariyada O (2002) Inactivation of Escherichia coli by microwave induced low temperature argon plasma treatments. J Food Eng 53:341-346

Rossi F, Kylian O, Rauscher H, Gilliland D, Sirghi L (2008) Use of a lowpressure plasma discharge for the decontamination and sterilization of medical devices. Pure Appl Chem 80:1939-1951

Roth S, Feichtinger J, Hertel C (2009) Characterization of Bacillus subtilis spore inactivation in low-pressure, low-temperature gas plasma sterilization processes. J Appl Microbiol. doi:10.1111/j. 1365-2672.2009.04453.x

Schütze A, Jeong JY, Babayan SE, Park J, Selwyn GS, Hicks RF (1998) The atmospheric-pressure plasma jet: a review and comparison to other plasma sources. IEEE Trans Plasma Sci 26:1685-1694

Selcuk M, Oksuz L, Basaran P (2008) Decontamination of grains and legumes infected with Aspergillus spp. and Penicillum spp. by cold plasma treatment. Bioresour Technol 99:5104-5109

Setlow P (2006) Spores of Bacillus subtilis: their resistance to and killing by radiation, heat and chemicals. J Appl Microbiol 101:514-525 
Shi X, Zhu X (2009) Biofilm formation and food safety in food industries. Trend Food Sci Tech 20:407-413. doi:10.1016/j.tifs.2009.01.054

Shintani H, Sakudo A, Birke P, McDonnell G (2010) Gas plasma sterilization of microorganisms and mechanisms of action (Review). Exp Ther Med 1:731-738

Sofos JN (1994) Microbial growth and its control in meat poultry and fish. In: Pearson AM, Dutson TR (eds) Quality attributes and their measurement in meat poultry and fish products, 1st edn. Blackie, London, pp 359-391

Song HP, Kim B, Choe JH, Jung S, Moon SY, Choe W, Jo C (2009) Evaluation of atmospheric pressure plasma to improve the safety of sliced cheese and ham inoculated by 3 -strain cocktail Listeria monocytogenes. Food Microbiol 26:432-436

Tang YJ et al (2007) Charge-associated effects of fullerene derivatives on microbial structural integrity and central metabolism. Nano Lett 7: 754-760

Tyagi AK, Malik A (2012) Morphostructural damage in food-spoiling bacteria due to the lemon grass oil and its vapour: sem, tem, and afm investigations. Evid Based Complement Alternat Med 2012: 692625. doi:10.1155/2012/692625
Ulbin-Figlewicz N, Zimoch-Korzycka A, Jarmoluk A (2014) Antibacterial activity and physical properties of edible chitosan films exposed to low-pressure plasma. Food Bioprocess Tech 08/2014. doi: 10.1007/ s11947-014-1379-6

von Kuedell A et al (2010) Inactivation of bacteria and biomolecules by low-pressure plasma discharges. Plasma Process Polym 7:327-352. doi:10.1002/ppap.200900121

Weidner S, Kühn G, Decker R, Roessner D, Friedrich J (1998) Influence of plasma treatment on the molar mass of poly (ethylene terephthalate) investigated by different chromatographic and spectroscopic methods. J Polym Sci A Polym Chem 36:1639-1648

Weltmann KD, Fricke K, Stieber M, Brandenburg R, von Woedtke T, Schnabel U (2012) New nonthermal atmospheric pressure plasma sources for decontamination of human extremities. IEEE Trans Plasma Sci. doi:10.1109/tps.2012.2204279

Zhang XS, Garcia-Contreras R, Wood TK (2007) YcfR (BhsA) influences Escherichia coli biofilm formation through stress response and surface hydrophobicity. J Bacteriol 189:3051-3062

Zhou GH, Xu XL, Liu Y (2010) Preservation technologies for fresh meat-a review. Meat Sci 86:119-128 